\title{
Spatial distribution of ammonia-oxidizing archaea and bacteria across eight freshwater lakes in sediments from Jiangsu of China
}

\author{
Xu SUN, Aili WANG, Liuyan YANG, ${ }^{*}$ Liyun GUO, Qiankun CHEN, Zhixin HU, Lijuan JIANG, Lin XIAO \\ State Key Laboratory of Pollution Control and Resource Reuse, School of the Environment, Nanjing University, Nanjing 210046, China \\ *Corresponding author: yangly@nju.edu.cn
}

\begin{abstract}
Ammonia-oxidizing archaea (AOA) and ammonia-oxidizing bacteria (AOB) play an important role in nitrogen transformation in freshwater sediment. However, it is still unclear to what extent the distribution patterns of these microorganisms are affected by the freshwater sediment across a large geographical scale. This study was designed to gain insight into the heterogeneity distribution of $A O A$ and $A O B$ in freshwater sediments from the macrophyte or algae dominated regions. Real-time quantitative PCR (qPCR) combined with the terminal restriction fragment length polymorphism (T-RFLP) were employed to characterize the abundance, diversity, and community structure of the $A O A$ and $A O B$ across eight freshwater lakes in sediments from Jiangsu of China. AOA and AOB were ubiquitous in all sediments, and archaeal amoA far outnumbered bacterial amoA in sediments with the lower concentration of organic matters. The abundance of $A O A$ and $A O B$ did not vary with the freshwater ecological type (macrophyte dominated region and algae dominated region). Based on the T-RFLP of an amoA gene, this research found that the concentration of organic matters in pore water rather than other factors affect the AOA community structure in sediments, while the AOB were not significantly different in the freshwater sediments. Phylogenetic analysis showed that all archaeal amoA sequences fell within either the Crenarchaeotal Group (CG) I.1b or the CGI.1 a subgroup, and all AOB clustered with genus Nitrosomonas or Nitrosospira. The data obtained in this study elucidates the role of ammonia-oxidizing archaea and ammonia-oxidizing bacteria in the nitrogen cycle of freshwater ecosystems.
\end{abstract}

Key words: ammonia-oxidizing archaea, ammonia-oxidizing bacteria, trophic status, nitrification, qPCR, T-RFLP.

Received: November 2013. Accepted: December 2013.

\section{INTRODUCTION}

Nitrification in coupled denitrification is a key stage in nitrogen cycling and removal (Herrmann et al., 2011). This process is oxidation of ammonia to nitrite, which is catalyzed by two groups of prokaryotes, the ammonia-oxidizing bacteria (AOB) and the recently recognized ammonia-oxidizing archaea (AOA). For both groups, the gene encoding the alpha-subunit of ammonia monooxygenase $(a m o A)$ has been widely used as a functional marker to analyze their community compositions. Recent studies demonstrated the wide distribution of AOA in aqueous environments by its existence in members of the Thaumarchaea I.1a (also named Marine Group I) or I.1b, showing the AOA predominance over AOB in a broad range of environments (Herrmann et al., 2009; Reed et al., 2010; Cao et al., 2011; Isobe et al., 2012). Environmental elements such as $\mathrm{pH}$, ammonia and dissolved oxygen (DO) concentrations, are important factors which define the differences between AOA and AOB in distinct ecological niches (Altmann et al., 2004; Erguder et al., 2009; Herrmann et al., 2011; Bouskill et al., 2012; Vissers et al., 2013). Of particular interest to these researchers was the determination of key environmental factors controlling the abundance and distribution of AOA and shaping of distinct ecological niches of AOA and AOB. The factors regulating the microbial community composition are usually complex involving multiple environmental variables. Understanding the spatial distribution of AOA and $\mathrm{AOB}$ in relation to different lake sediment is important, especially in sediment because it is main place for nitrogen transformation in lake ecosystems.

Up to now, because of these concerns and the role of ammonia oxidizers in nitrogen cycling in general, it is still argued that the geographical distribution of AOA and AOB must be delineated to understand their relationship or effect on different lakes sediment. From oligotrophic lakes to mesotrophic lakes, the diversity of AOA and AOB increases, especially in eutrophic lake sediment where the abundance and community of AOB are greater than that in oligotrophic lake sediment (Chen et al., 2009; Herrmann et al., 2009; Hou et al., 2013; Hugoni et al., 2013). In Lake Taihu sediment, AOA outnumbered AOB in lake zones dominated with algal bloom. No significant differences in the relative abundance or the community composition of AOA and AOB appeared in sediments or freshwater between algae type (A) and macrophyte type (M) zones (Wu et al., 2010; Auguet and Casamayor, 2013). However, due to the complexity of the lake ecosystem and the lack of geochemical information, most of these previous investigations focused on a limited 
number of freshwater sediment samples or lakes; therefore, it was still not known if the niche separations between $\mathrm{AOA}$ and $\mathrm{AOB}$ held true across large-scale freshwater ecosystems. A different type of ecological research needed to be conducted to understand the distribution of ammonia-oxidizing prokaryotes and their dynamics and impaction factors.

This study was designed to gain insight into the heterogeneity distribution of AOA and AOB in freshwater sediment from 3 distinct ecological types (algae type, transitional type and macrophyte type). To address these aims, the sediment sample of eight lakes, each with a different ecosystem when compared to the others, were chosen to investigate the relationships of ecological type and physicochemical factors as they relate to the distribution of ammonia-oxidizing archaea and ammonia-oxidizing bacteria. Characterized respectively by real-time quantitative PCR (qPCR) and the terminal restriction fragment length polymorphism (T-RFLP), the abundance, community composition and diversity of ammonia-oxidizing prokaryotes were analyzed to extend our knowledge about the heterogeneity distribution of $\mathrm{AOA}$ and $\mathrm{AOB}$ in freshwater sediments from different ecological types.

\section{METHODS}

\section{Sampling site description and sample collection}

Lake sediment samples were taken from four mesotrophic lakes (Lake Luoma, Lake Baima, Lake Gaoyou, Lake Gucheng) and four eutrophic lakes (Lake Taihu, Lake Shijiu, Lake Xuanwu and Lake Hongze) in Jiangsu Province, China (Fig. 1). Based on previous descriptions (Qin, 2009) and the data from our survey on the ratio of submersed plants and phytoplankton in different seasons from each of the different lakes, all sites could be clearly characterized as algae type zones (with an average ratio below 1) or transitional type zones (with an average ratio between 1 and 100) and macrophyte type zones (with an average ratio above 100) in the different lakes (Tab. 1; Supplementary Tab. 1).

Sediment cores were collected during May 20-21, 2012 (spring samples) using a beaker-type sampler, and the surface sediment of $1 \mathrm{~cm}$ was transferred to a sterile

Tab. 1. Physicochemical characteristics of pore water from the surface lake sediment.

\begin{tabular}{|c|c|c|c|c|c|c|c|}
\hline & $\mathrm{pH}$ & $\begin{array}{c}\mathrm{NO}_{3}{ }^{-} \mathrm{N} \\
(\mathrm{mg} / \mathrm{kg})\end{array}$ & $\begin{array}{l}\mathrm{NH}_{4}{ }^{+}-\mathrm{N} \\
(\mathrm{mg} / \mathrm{kg})\end{array}$ & $\begin{array}{c}\text { DIP } \\
(\mathrm{mg} / \mathrm{kg})\end{array}$ & $\begin{array}{c}\text { TOC } \\
(\mathrm{mg} / \mathrm{kg})\end{array}$ & $\mathrm{C}: \mathrm{N}$ & Type \\
\hline LM1 & 7.18 & 0.18 & 8.09 & 0.04 & 127.83 & 15.46 & $\mathrm{~T}$ \\
\hline LM2 & 7.20 & 0.20 & 7.01 & 0.04 & 114.83 & 15.93 & $\mathrm{~T}$ \\
\hline LM3 & 7.26 & 0.26 & 9.15 & 0.04 & 117.83 & 12.52 & $\mathrm{~T}$ \\
\hline BM1 & 7.12 & 1.44 & 8.54 & 0.02 & 254.70 & 25.52 & $\mathrm{~T}$ \\
\hline BM3 & 7.14 & 2.22 & 14.24 & 0.02 & 294.55 & 17.89 & M \\
\hline GC1 & 6.87 & 0.86 & 9.94 & 0.03 & 176.50 & 16.34 & $\mathrm{~T}$ \\
\hline GC3 & 7.10 & 0.29 & 16.68 & 0.04 & 83.65 & 4.93 & $\mathrm{~T}$ \\
\hline GY1 & 6.98 & 0.58 & 11.70 & 0.05 & 83.30 & 6.78 & $\mathrm{~T}$ \\
\hline GY2 & 7.42 & 0.46 & 10.07 & 0.14 & 51.45 & 4.89 & $\mathrm{~T}$ \\
\hline GY3 & 7.05 & 0.41 & 9.08 & 0.05 & 167.10 & 17.61 & M \\
\hline XW1 & 7.33 & 0.16 & 7.49 & 0.06 & 91.73 & 11.99 & A \\
\hline XW2 & 7.14 & 0.36 & 10.12 & 0.02 & 113.73 & 10.85 & A \\
\hline XW3 & 7.14 & 0.26 & 8.32 & 0.02 & 95.58 & 11.14 & A \\
\hline SJ1 & 6.61 & 2.06 & 18.65 & 0.01 & 162.85 & 7.86 & A \\
\hline $\mathrm{SJ} 2$ & 6.87 & 0.35 & 11.20 & 0.01 & 91.13 & 7.89 & A \\
\hline $\mathrm{SJ} 3$ & 7.17 & 0.35 & 13.62 & 0.02 & 90.25 & 6.46 & A \\
\hline $\mathrm{T} 2$ & 7.11 & 2.29 & 29.12 & 0.11 & 48.33 & 1.54 & A \\
\hline $\mathrm{T} 4$ & 7.38 & 0.44 & 14.37 & 0.02 & 19.82 & 1.34 & A \\
\hline T5 & 7.49 & 0.81 & 12.97 & 0.02 & 47.95 & 3.48 & A \\
\hline $\mathrm{T} 8$ & 7.39 & 1.20 & 9.77 & 0.01 & 22.19 & 2.02 & $\mathrm{~T}$ \\
\hline $\mathrm{T} 10$ & 6.92 & 1.59 & 16.17 & 0.03 & 64.45 & 3.63 & M \\
\hline S2 & 7.41 & 1.13 & 8.89 & 0.05 & 25.60 & 2.55 & $\mathrm{~T}$ \\
\hline S4 & 7.39 & 0.41 & 11.07 & 0.04 & 35.90 & 3.13 & A \\
\hline HZ1 & 7.65 & 0.32 & 6.78 & 0.00 & 59.28 & 8.35 & A \\
\hline HZ3 & 7.87 & 0.25 & 10.44 & 0.05 & 33.10 & 3.10 & A \\
\hline HZ6 & 7.73 & 0.22 & 7.77 & 0.07 & 53.40 & 6.68 & A \\
\hline HZ7 & 7.56 & 0.29 & 13.99 & 0.03 & 27.20 & 1.90 & A \\
\hline HZ8 & 7.69 & 0.82 & 12.80 & 0.00 & 43.05 & 3.16 & A \\
\hline HZ9 & 7.71 & 1.05 & 16.40 & 0.01 & 69.78 & 4.00 & A \\
\hline
\end{tabular}

DIP, Dissolved inorganic phosphorus; $\mathrm{TOC}$, total organic carbon; $\mathrm{C}: \mathrm{N}$ means the ratio of total dissolve organic matters to nitrogen $\left(\mathrm{NO}_{3}^{-}-\mathrm{Nplus}^{-} \mathrm{H}_{4}^{+}-\mathrm{N}\right)$; T, transitional-type zone; $M$, macrophyte-type zone; A, algae-type zone; the ecological type of the lake zones could be divided by the average ratio of submerged plants to phytoplankton according to the Supplementary Tab. 1. 
tube. The sediment samples were transported on ice to the laboratory, and one part was used for chemical analysis, while another was stored at $-80^{\circ} \mathrm{C}$ until measurement could be taken.

\section{Chemical analysis of pore water quality in sediment}

The chemical matter concentrations were measured in pore water of centrifuged sediments passed through 0.45 $\mu \mathrm{m}$ mixed-fiber membrane. Total organic carbon (TOC) contents in pore water of sediment were analyzed by SHIMADZU TOC-5000A. Dissolved inorganic phosphorus (DIP) was determined by persulfate oxidation and spectrophotometry using a Shimadzu UV 2450 spectrophotometer. The aqueous $\mathrm{NO}_{3}{ }^{-} \mathrm{N}$ and $\mathrm{NH}_{4}{ }^{+}-\mathrm{N}$ concentrations were detected by UV-spectrophotometry, N-(1-naghthyl)-1, 2-diaminoethane dihydrochloride spectrophotometry and Nessler's Reagent Spectrophotometry.

\section{DNA extraction and amplification of archaeal and bacterial $a m o A$}

Total DNA was extracted from $0.25 \mathrm{~g}$ of lyophilized sediment using a Power DNA Extracted Kit (Mo Bio, Carlsbad, CA, USA) following the manufacturer protocol. The quantity and the quality of DNA were determined using NanoDrop spectrophotometer 2000 (NanoDrop
Technologies Inc, Wilmington, DE, USA). For terminal restriction fragment length polymorphism (T-RFLP) and cloning analysis, archaeal amo $A$ fragments were amplified with primers Arch-amoAF and Arch-amoAR set (Di et al., 2009; Covich et al., 1999). The $25 \mu \mathrm{L}$ PCR mixture contained $1 \times \mathrm{PCR}$ buffer, $2.0 \mathrm{mM} \mathrm{MgCl} 2,200 \mu \mathrm{M}$ of each dNTP, 1.5 U ExTaq DNA polymerase (Takara, Dalian, China), $0.5 \mu \mathrm{M}$ of each primer and $0.5 \mu \mathrm{L}$ of purified sediment DNA. The PCR protocol described by Francis (Francis et al., 2005) was followed using 35 cycles. Bacterial amo $A$ was amplified using a similar protocol as for archaeal amoA using the primer set amoA-1F/amoA-2R-TC set (Rotthauwe et al., 1997). The PCR was run for 30 cycles.

\section{Real-time PCR analysis of archaeal and bacterial amo $A$}

Real-time PCR was performed to quantify the archaeal and bacterial amoA copy numbers using the primer sets Arch-amoAF/Arch-amoAR and amoA-1F/amoA-2R-TC, respectively. The quantification was based on SYBR Green II chemistry, with a total of 40 cycles run on a Bio-Rad CFX96 real-time System (Bio-Rad Laboratories, Hercules, $\mathrm{CA}$, USA). Each reaction was performed in a $20 \mu \mathrm{L}$ volume containing 5-29 ng of template DNA, $0.2 \mu \mathrm{M}$ of each primer and $10 \mu \mathrm{L}$ of SYBR II Premix Ex TaqTM (Takara, Dalian, China). The specificity of the PCR was checked by

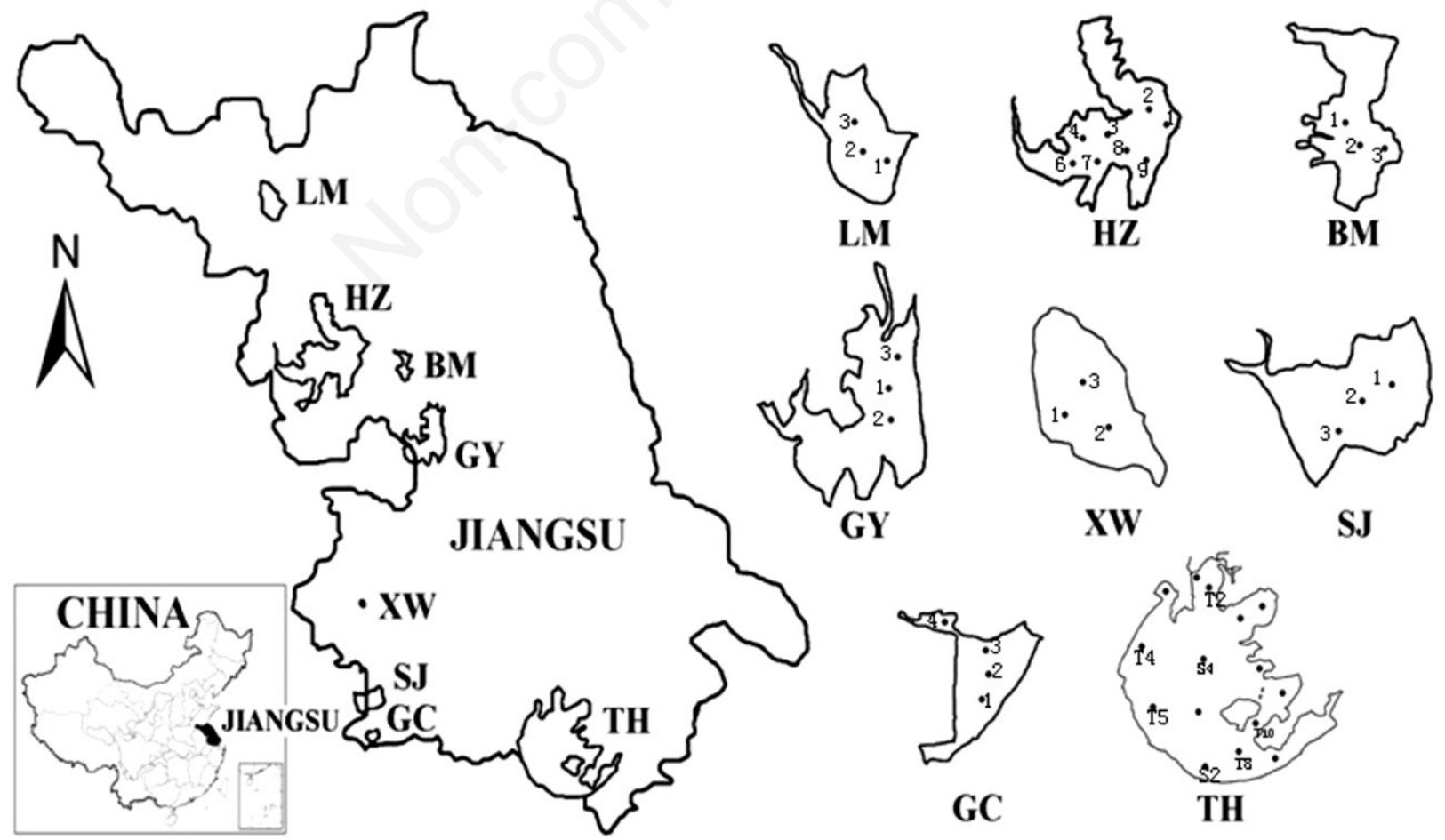

Fig. 1. Black dots and numbers represent the sampling site location in different lakes. 
melting curve analysis and gel electrophoresis. The environmental DNA extracts did not inhibit PCR amplification using the methods described by Horz and Kontanis (Horz et al., 2004; Kontanis and Reed, 2006).

Ten-fold serial dilutions of plasmid DNA of a known concentration were prepared for the construction of a standard curve covering six orders of magnitude $\left(1.0 \times 10^{1}\right.$ to $1.0 \times 10^{6}$ copies of template for archaeal amoA and $1.0 \times 10^{2}$ to $1.0 \times 10^{7}$ copies of template for bacterial amoA). The amplification efficiencies were $91.8 \%$ for archaeal amo $A$ $\left(\mathrm{R}^{2}=1.00\right)$ and $90.2 \%$ for bacterial amoA $\left(\mathrm{R}^{2}=0.99\right)$, respectively. Data analysis was carried out with iCycler software, ver. 1.0.1384.0 CR. The parameter $\mathrm{Ct}$ (threshold cycle) was determined as the cycle number at which a statistically significant increase in the reporter fluorescence was detected.

\section{Terminal restriction fragment length polymorphism analysis of $a m o A$ genes}

T-RFLP analysis of bacterial amoA genes was performed according to (Ke and Lu, 2012). Briefly, each PCR amplification was performed in triplicate using the primer pair amoA-1Fand amoA-2R with the forward primer FAM-labeled. Amplicons were digested with MspI (Takara), and after the purification, the digestion products were mixed with formamide and the internal standard DNA size standard $600 \mathrm{bp}$ (Beckman). The mixture was denatured at $95^{\circ} \mathrm{C}$ for 3 min and DNA fragments were size-separated using a CEQ8000 Genetic Analyzer (Beckman CEQ8000). For T-RFLP analysis of archaeal amoA genes, the FAM-labeled archaeal-AF and archaeal-AR primer pair were used (Francis et al., 2005). Amplicons were digested with Hpy8I (Saiyanbio, Nanjing, China), and the digestion products were analyzed similarly as for the bacterial amo $A$ genes.

\section{Cloning, sequencing and phylogenetic analysis}

The products of triplicate PCR amplifications of archaeal or bacterial amoA were pooled, gel purified and cloned using the pMD-19T Vector (Takara) according to the manufacturer instructions. Putative clones were screened directly by PCR using the primer sets ArchamoAF/Arch-amoAR for archaea and amoA-1F/amoA2R-TC for bacteria, and randomly selected clones containing the inserts were sequenced (Genomics, Shanghai, China). Operational taxonomic units (OTUs) estimators were calculated using Mothur (Schloss et al., 2009). Retrieved archaeal $a m o A$ and bacterial $a m o A$ sequences as well as the closest matched sequences identified using BLAST (http://blast.ncbi.nlm.nih.gov/Blast.cgi) were aligned using CLUSTAL X 1.83. Phylogenetic trees were constructed based on a 3\% cut-off using the neighborjoining method based on the Jukes-Cantor correction (ar- chaeal amoA) and Jones-Taylor-Thornton substitution model (bacterial amoA) by MEGA version 5. Bootstrap support was calculated (1000 replications).

The sequences obtained in this study have been deposited in GenBank with accession numbers KC756621KC756795 (environmental archaeal amoA clones except $\mathrm{KC} 756635$ ) and KC756422-KC756620 (environmental bacterial amo $A$ clones except KC756596).

\section{Statistical analysis}

Analysis of variance (ANOVA) and correlation analysis were performed using the SPSS 18.0 package (SPSS, Chicago, IL), with values of 0.05 or 0.01 selected for significance. The size and relative abundance of terminal restriction fragments (T-RFs) were quantified using PeakScan version 1.0 software (Applied Biosystems, Inc., Carslbad, CA, USA). The peak heights of T-RFs that differed in size by $\leq 2 \mathrm{bp}$ in an individual profile were summed and considered as one fragment; furthermore, the fragments with a signal above $1 \%$ of the sum of all peak heights were included (Chen et al., 2012). The community structures of $\mathrm{AOB}$ and AOA derived from T-RFLP fingerprints were analyzed by non-metric multidimensional scaling (NMS) using PC-ORD version 5.10 (MjM Software, Gleneden Beach, OR, USA). To summarize, data matrices of the community fingerprints were arc-sinus square root transformed, and the Bray-Curtis distance measure was used to generate dissimilarity matrices. The data in the second matrix were relativized by dividing values within each variable by column totals. The NMS was run using a random starting configuration, a maximum of 250 iterations and an instability criterion of 0.00001 and performed on 250 runs with the real data and 250 runs with randomized data to test for the null hypothesis. For a two-dimensional solution with the lowest possible stress value, a final run using the best starting configuration from the first run was performed.

\section{RESULTS}

\section{Physicochemical properties of sediment from different lakes}

The physicochemical properties of sediments sampled from eight lakes were different (Tab. 1; Fig. 2). Based on current literature and our measured data of ecological types, the water body was divided into three categories. Among the different ecological type lake zones, a great variance in physicochemical parameters was observed. For example, the greatest $\mathrm{NO}_{3}{ }^{-} \mathrm{N}$ content in sediment (2.29 $\mathrm{mg} \mathrm{kg}^{-1}$ at site BM3) was 14.1 times higher than the lowest values $\left(0.16 \mathrm{mg} \mathrm{kg}^{-1}\right.$ at site XW1) (Tab. 1). The concentration of organic matters in pore water of sediment was about 20 times (394.55 mg kg-1 at site BM3) in macrophyte type zone higher than that in algae type zone (19.82 $\mathrm{mg} \mathrm{kg}^{-1}$ at site T4). The ratios of C:N in most algae 
type zones were lower than that in transitional type zones or macrophyte type zones.

\section{Abundance of ammonia-oxidizing archaea and ammonia-oxidizing bacteria}

Quantitative PCR analysis indicated that the abundance of $\mathrm{AOA}$ and $\mathrm{AOB}$ extensively varied with different lakes sediment (Fig. 3). The archaeal amoA gene copy numbers ranged from $6.6 \times 10^{4}$ per gram of dry sediment at site BM1 in transitional-type zone to $3.9 \times 10^{7}$ per gram of dry sediment at site HZ6 in algae-type zone, whereas the bacterial amo $A$ gene copy numbers ranged from $2.6 \times 10^{5}$ per gram of dry sediment at site BM3 in macrophyte-type zone to $2.4 \times 10^{7}$ per gram of dry sediment at site GY1 in transitional-type zone. However, the archaeal and bacterial amo $A$ gene copy numbers did not vary in sediments with the ecological types, for example in some algae type zones (XW and SJ) archaeal or bacterial amoA gene copy numbers were lower than those in some transitional type (S2,T8, GY2 or GC1, GC3, GY1), whereas in other algae-type zones (HZ lakes) archaeal or bacterial amoA gene copy numbers were higher than those in transitional type zones (LM1, LM2 and BM1). Consequently, the ratio of AOA to AOB varied from 17 at site $\mathrm{T} 7$ to 0.03 at site BM1 by almost four orders. The archaeal amoA gene copy numbers were higher than the bacterial amoA gene (excluding XW1, XW2, XW3, SJ1, SJ2 with the higher concentration of or- ganic matters), whereas the bacterial amo $A$ were more abundant than archaeal amo $A$ in the transitional-type sediments excluding GY2, S2, T8 and T10 with the lower concentration of organic matters. It indicated that the content of organic matters rather than the ecological type of the lakes might play an important role in affecting the distribution of AOA and AOB. Pearson's correlation coefficients were used to investigate the correlations between the lake properties and the AOA or AOB abundance (Tab. 2). A significant relationship between environmental factors and the archaeal $a m o A$ gene numbers instead of the bacterial amo $A$ gene numbers was observed. There were strong correlation between archaeal amoA gene numbers and $\mathrm{pH}$, as well as total organic matter (TOC) content in the sediment respectively $\left(\mathrm{R}^{2}=0.612, \mathrm{P}<0.01 ; \mathrm{R}^{2}=-0.485, \mathrm{P}<0.01\right.$, respectively) (Wu et al., 2010). The relative abundance of AOA and AOB amoA gene numbers also correlated with $\mathrm{pH}$ and TOC, which were the result of a correlation between the archaeal amo $A$ gene numbers and the relative abundance of AOA and $\mathrm{AOB}$ indicating that $\mathrm{AOA}$ might play an important role in poor organic sediments (Tab. 2).

\section{Phylogenetic affiliation of $a m o A$ sequences}

Ten clone libraries (in sediments from T2, T4, XW1, HZ6, HZ1, SJ1, SJ3, BM1, GC1 and T10 sites) representing eutrophic zones, estuaries and mestotrophic zones were constructed to elucidate the phylogeny of amo $A$
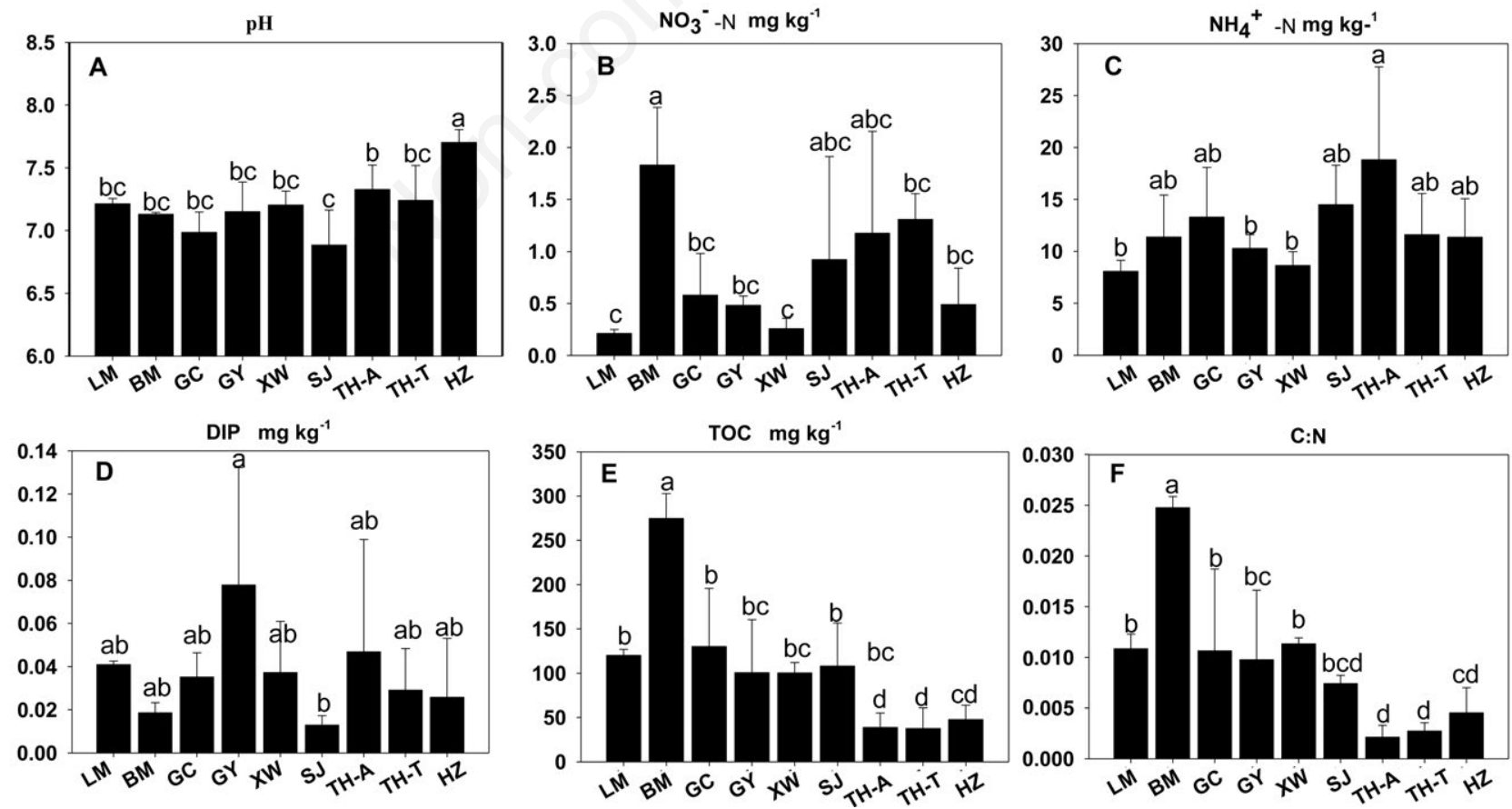

Fig. 2. Spatial variance in A) $\mathrm{pH}$; B) $\mathrm{NO}_{3}^{-}-\mathrm{N}$; C) $\mathrm{NH}_{4}{ }^{+}-\mathrm{N}$; D) dissolved inorganic phosphorus (DIP); E) total organic carbon (TOC); $\mathrm{F}), \mathrm{C}: \mathrm{N}$ ratio in pore water of sediment. Bars with the same letter are not significantly different $(\mathrm{P}>0.05)$. 
genes (Fig. 4; Tab. 3). For archaeal amoA library, 17-31 clones were randomly selected and sequenced. Based on a $3 \%$ cut-off, 19 operational taxonomic units (OTUs) out of 142 clones were identified (Tab. 3). Among the 142 aracheal amoA sequences retrieved, $93.1 \%$ and $6.9 \%$ fell within the Crenarchaeotal Group (CG) I.1a (M) and the CG I.1b (S) respectively (Fig. 4). The sequences affiliated with the Crenarchaeotal Group (CG) I.1b (S) were all derived from sediment in the eutrophic zones, whereas in the CG I.1a (M), the sequences came from both zones. These sequences can be further classified into six subclusters with most sequences falling within subclusters $\mathrm{S} 3$, M1 and M2 (Fig. 5). And subcluster M2 was dominated at all sites. Five of the T-RFs detected (T-RF56, T-RF196, T-RF239 and T-RF635) could be assigned to define phylogenetic groups, and T-RF 56 was detected in more than one phylogenetic group. Other T-RFs (T-RF196, TRF239, and T-RF635) were only detected in one phylogenetic group. Most sequences were related to Nitrosopumilus maritimus SCM1 sequences (T-RF56), and Candidatus Nitrososphaera gargensis-related sequences (T-RF196, T-RF635) were only detected in Crenarchaeotal Group (CG) I.1b (S).

For bacterial amoA library, 19-34 clones were ran-

Tab. 2. The correlations between abundance of amoA genes copies and environment factors of pore water from sediments.

\begin{tabular}{lccc}
\hline & \multicolumn{3}{c}{ Abundance $^{\circ}$} \\
\cline { 2 - 4 } & AOA & AOB & AOA:AOB \\
\hline $\mathrm{pH}$ & $0.612^{* *}$ & -0.188 & $0.390^{*}$ \\
$\mathrm{NO}_{3}{ }^{-} \mathrm{N}$ & -0.045 & -0.220 & 0.105 \\
$\mathrm{NH}_{4}{ }^{+} \mathrm{N}$ & -0.072 & -0.113 & -0.008 \\
$\mathrm{DIP}$ & 0.222 & 0.137 & 0.002 \\
$\mathrm{TOC}$ & $-0.485^{* *}$ & -0.013 & $-0.520^{* *}$ \\
$\mathrm{C}: \mathrm{N}$ & $-0.477^{*}$ & 0.045 & $-0.556^{* *}$ \\
\hline
\end{tabular}

${ }^{\circ}$ Pearson correlation coefficient; $A O A$, ammonia-oxidizing archaea; $A O B$, ammonia-oxidizing bacteria; significance at ${ }^{*} \alpha=0.05$ level; ${ }^{* *} \alpha=0.01$ level.

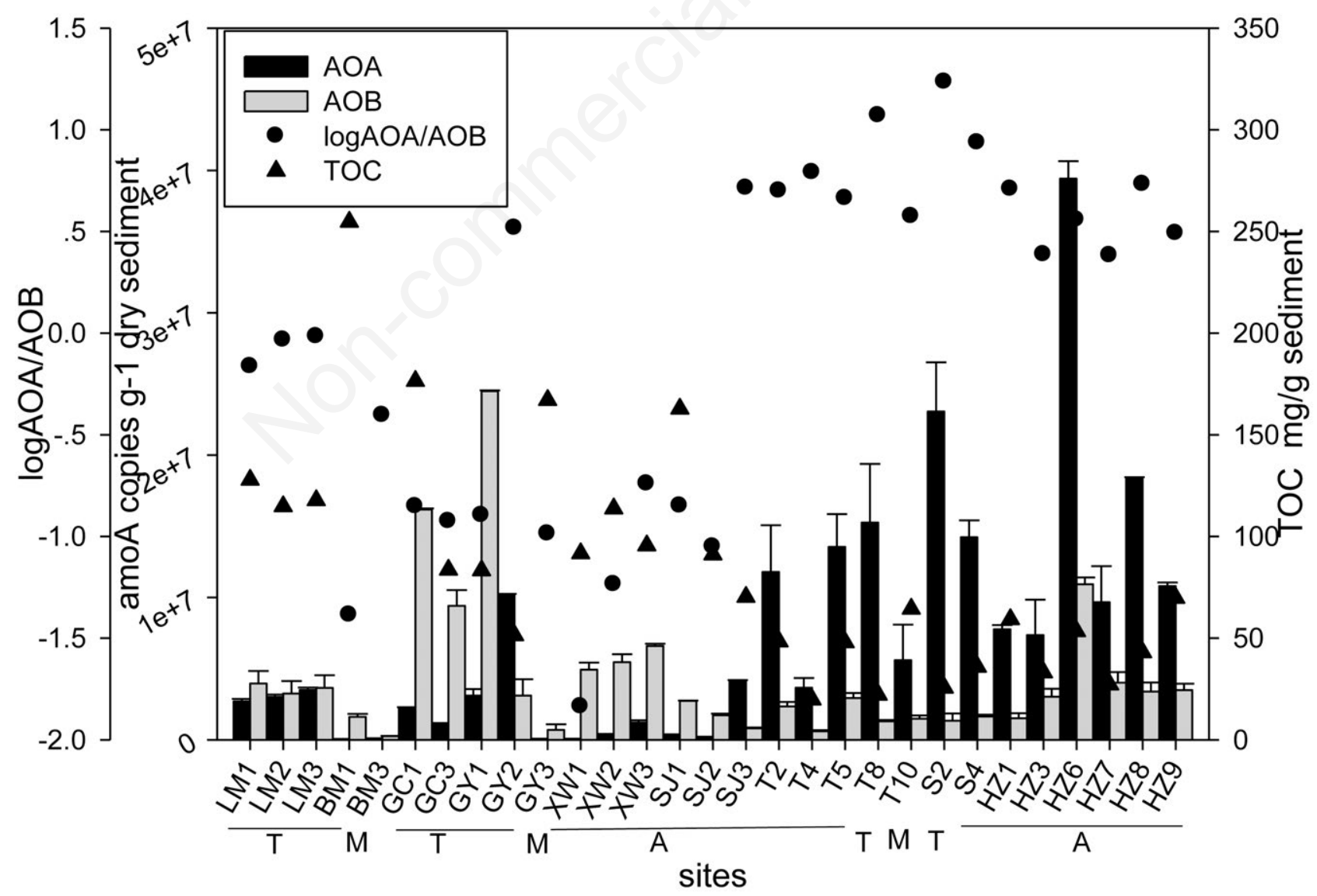

Fig. 3. Abundance of ammonia-oxidizing archaea (AOA; black bar) and ammonia-oxidizing bacteria (AOB; grey bar) are expressed as amo $A$ gene copies; the ratio of AOA and AOB are represented by a circle scatters in the sediments. The content of total organic matters are shown by a triangle scatters in different lakes sediment. A, algae-type zones; M, macrophyte-type zones; T, transitional-type zones. 
domly selected and sequenced. Based on a 3\% cut-off, 26 operational taxonomic units from 194 clones were identified, among which $60.4 \%$ and $18.7 \%$ fell within the $\mathrm{Ni}$ trosospira-like sequences and Nitrosomonas oligotrophal ureae sequences respectively (Fig. 4). Nitrosospira-like sequences were ubiquitous and dominated at all sites, whereas most Nitrosomonas communis sequences appeared in eutrophic zones. Eight of the T-RFs detected (T-RF60, T-RF97, T-RF104, T-RF154, T-RF234, T-RF256, T-RF264 and T-RF491) could be assigned to define phylogenetic groups, and T-RF-60, T-RF-104, T-RF-154 were detected in Nitrosospira. Other T-RFs were only detected in Nitrosomonas sequences. Most sequences were related to Nitrosospira sequences (T-RF-60).

\section{The community structure of ammonia-oxidizing archaea and ammonia-oxidizing bacteria in sediments}

The T-RFLP profiles generated by each enzyme of the amplified amoA genes from the AOB and AOA communities consisted of five to eight dominant and several minor peaks. When combining profiles from the corresponding enzymes, the total numbers of peaks were 32 and 31 for AOB and AOA, respectively. The NMS ordination revealed that the community structure of AOA depended on some environmental factors in the sediment, while the community structure of AOB were not changed (Fig. 6). Differences in community structure among the samples for AOA community were supported by final stress values (9.7), the Monte Carlo test $(\mathrm{P}<0.005 ; 500$ permutations), and the strong correlation between distances in the two-dimensional ordination space and the original space $\left(\mathrm{R}^{2}=0.95\right)$. For the AOA communities, no separation appeared among different ecological type zones, and the bi-plot showed that the separation of sites was mainly explained by the ratio of C:N and TOC along axis $1(28.3 \%)$.

\section{DISCUSSION}

Freshwater sediment as well as the seawater emerged as one of the largest reservoirs of archaeal diversity; however, the distribution pattern of these prokaryotes is still not clear in lake ecosystems with different ecological types. In our study, AOA and $\mathrm{AOB}$ were both ubiquitous in the freshwater sediments. The size and structure of the $\mathrm{AOB}$ and AOA communities at the sites were not randomly distributed but instead exhibited spatial patterns. These results agree with previous work showing that $\mathrm{AOB}$ and $\mathrm{AOA}$ communities exhibit biogeographical patterns across freshwater or soil ecosystems (Beman and Francis, 2006; Bannert et al., 2011; Auguet and Casamayor, 2013). The spatial patterns in the freshwater system showed that the AOB abundance decreased when the AOA increased with the lower concentration of organic matters indicating that $\mathrm{AOB}$ and $\mathrm{AOA}$ communities were influenced by different environmental factors. The correlations suggest that the AOA abundance was negatively influenced by the total dissolved organic carbon and nitrogen content in the pore water of the sediment as well as its $\mathrm{pH}$ reading, whereas no significant correlations were found between the AOB abundance and environmental factors.

It appeared that $\mathrm{AOA}$ were physiologically inhibited by the accumulation of organic matters, and AOA may not be so important in organic matters-rich environment (Konneke et al., 2005; Wesséna et al., 2010; Wu et al., 2010; Tournaa et al., 2011). This negative correlation between the AOA abundance and TOC could be due to the competition of ammonia oxidizers with $\mathrm{N}$-demanding heterotrophs for available ammonia and oxygen since the latter would be favored in high $\mathrm{C}: \mathrm{N}$ ratio. Because a higher $\mathrm{C}$ and $\mathrm{N}$ content in the sediment could lead to a higher mineralization rate and release of nutrients, our results implied that AOA are favored in the habitats that are poor in nutrients. This is supported by recent works reporting that $\mathrm{AOA}$ are adapted to low-nu-

Tab. 3. The observed and estimated richness of archaeal and bacterial $a m o A$ gene libraries in sediments.

\begin{tabular}{|c|c|c|c|c|c|c|c|c|}
\hline \multirow[t]{2}{*}{ Sampling location } & \multicolumn{4}{|c|}{$\mathrm{AOA}$} & \multicolumn{4}{|c|}{$\mathrm{AOB}$} \\
\hline & numbers & OTU & Chao1 & Shannon & Cloned numbers & OTU & Chaol & Shannon \\
\hline $\mathrm{TH} 2$ & 15 & 3 & 3.0 & 0.7 & 10 & 3 & 3 & 0.94 \\
\hline TH4 & 15 & 6 & 6.3 & 1.6 & 19 & 6 & 7 & 1.63 \\
\hline TH10 & 16 & 3 & 4.0 & 0.5 & 18 & 5 & 11 & 0.84 \\
\hline HZ6 & 25 & 4 & 4.0 & 0.9 & 21 & 3 & 3 & 0.84 \\
\hline $\mathrm{HZ1}$ & 21 & 4 & 4.0 & 1.1 & 25 & 5 & 11 & 0.66 \\
\hline SJ1 & 15 & 7 & 10.0 & 1.7 & 22 & 1 & 1 & 0 \\
\hline SJ3 & 19 & 4 & 7.0 & 0.6 & 19 & 9 & 14 & 1.98 \\
\hline BM1 & - & - & - & - & 14 & 7 & 13 & 1.77 \\
\hline $\mathrm{GC} 1$ & 16 & 1 & 1.0 & 0.0 & 26 & 4 & 4 & 0.97 \\
\hline XW1 & - & - & - & - & 20 & 6 & 7.5 & 1.33 \\
\hline Total & 142 & 19 & 31.0 & 2.1 & 194 & 26 & 41.6 & 2.1 \\
\hline
\end{tabular}

AOA, Ammonia-oxidizing archaea; AOB, ammonia-oxidizing bacteria; OTU, operational taxonomic unit; OTUs were defined as $3 \%$ difference in nucleic acid sequences alignment for both archaeal and bacterial amoA. Null means the lack of detection. 
trient conditions (Erguder et al., 2009; Wessen et al., 2011; Hou et al., 2013). Aquatic macrophytes are the main primary producers and one of the most important sources for sediment organic matters in most macrophytes type or transitional type lake zones; they can form black organic carbon compounds, generate ammonia as the end-product in de- composition process, and decrease $\mathrm{pH}$ and redox potential in sediments, whereas high algal biomass instead of macrophytes appear in most A-type lake zones, where the suspended sediments are prone to be oxidized leading to lower organic matters and high $\mathrm{pH}$ in sediments, especially when algal blooms occur. The concentration of nutrients such as
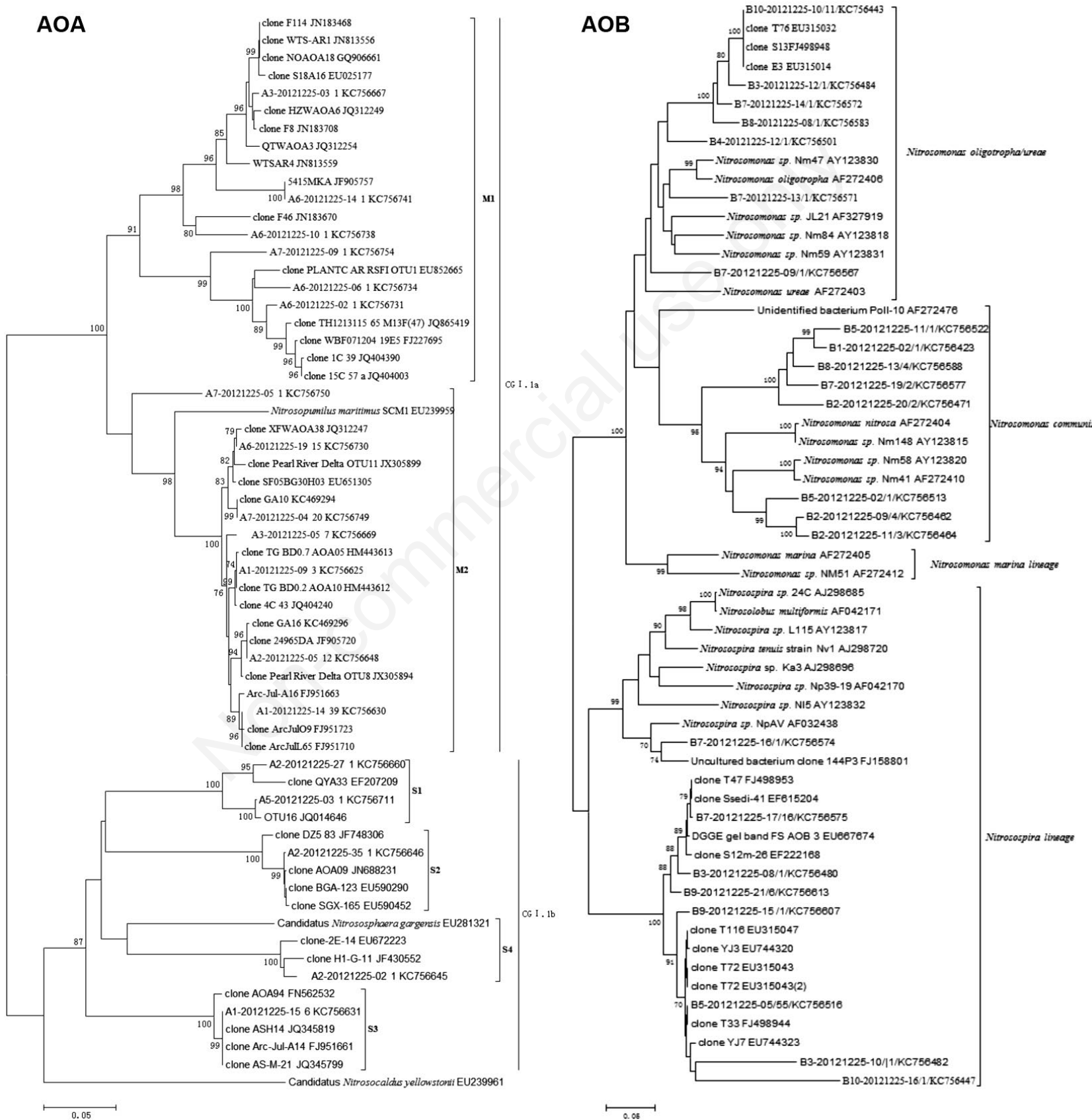

Fig. 4. Neighbor-joining phylogenetic trees of archaeal $\operatorname{amo} A(\mathrm{~A})$ and bacterial $a m o A(\mathrm{~B})$ show the representative sequences retrieved in this study with similarity less than $97 \%$ for each library, key reference sequences and closest matched sequences. Only bootstrap values higher than $70 \%$ are shown near nodes. The nomenclatures of clusters for AOB follow Purkhold et al. (2003). Numbers in parentheses indicate the number of sequences affiliated to the same operational taxonomic unit (OTU). 
ammonia assimilated by algae decreased dramatically in sediments from A-type lake zones (Scheffer et al., 1993; Covich et al., 1999; Williamson et al., 1999; Qinglong et al., 2013). Although XW and SJ lakes were A-type, they were affected by domestic sewage and fish farming respectively, resulting in higher $\mathrm{C}$ and $\mathrm{N}$ content in the sediment. While in the zones (T8, T10 and S2) Potamogeton spp. and Ceratophyllum spp. were the dominant submerged plants, and their roots did not reach the surface of sediment result- ing in limited effects of the root on the microbial activity in sediment owing to the release of oxygen and organic carbon from their roots (Wu et al., 2010). In the sediments pore water, $\mathrm{pH}$ was a differentiating factor for the $\mathrm{AOB}$ and AOA habitats as has been discussed previously, but there were conflicting results with some studies showing a negative correlation to $\mathrm{pH}$, and others showing that in most soils, the AOA were negatively impacted by low $\mathrm{pH}$ as in our study (He et al., 2007; Di et al., 2009; Hallin et al.,
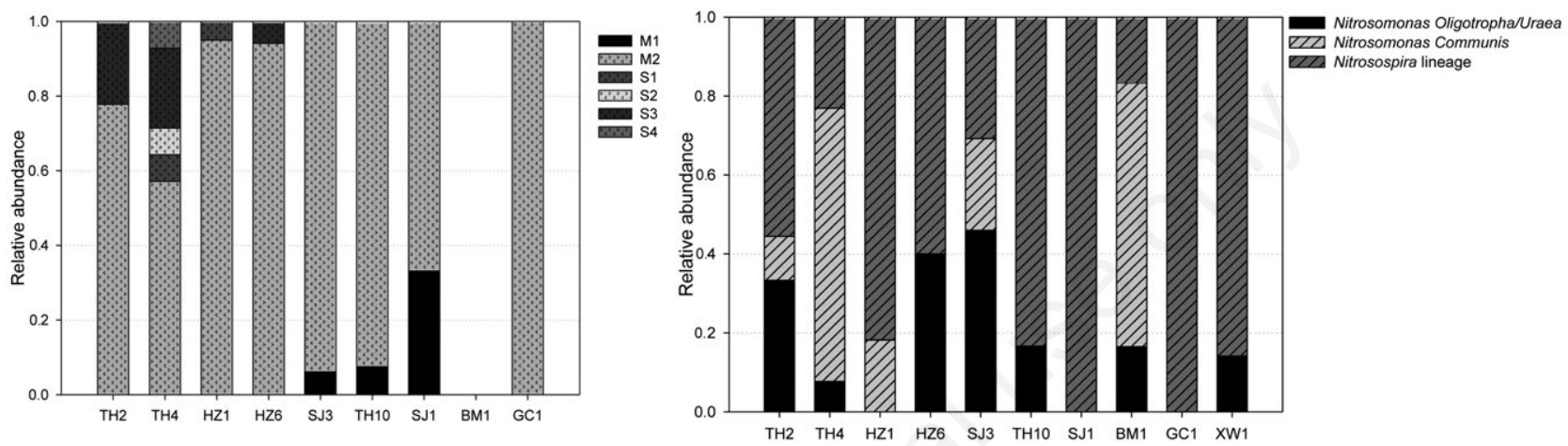

Fig. 5. The relative abundance of archaeal $\operatorname{amoA}(\mathrm{AOA})$ and bacterial amoA (AOB) gene clone libraries are shown here at ten sites from different lakes.

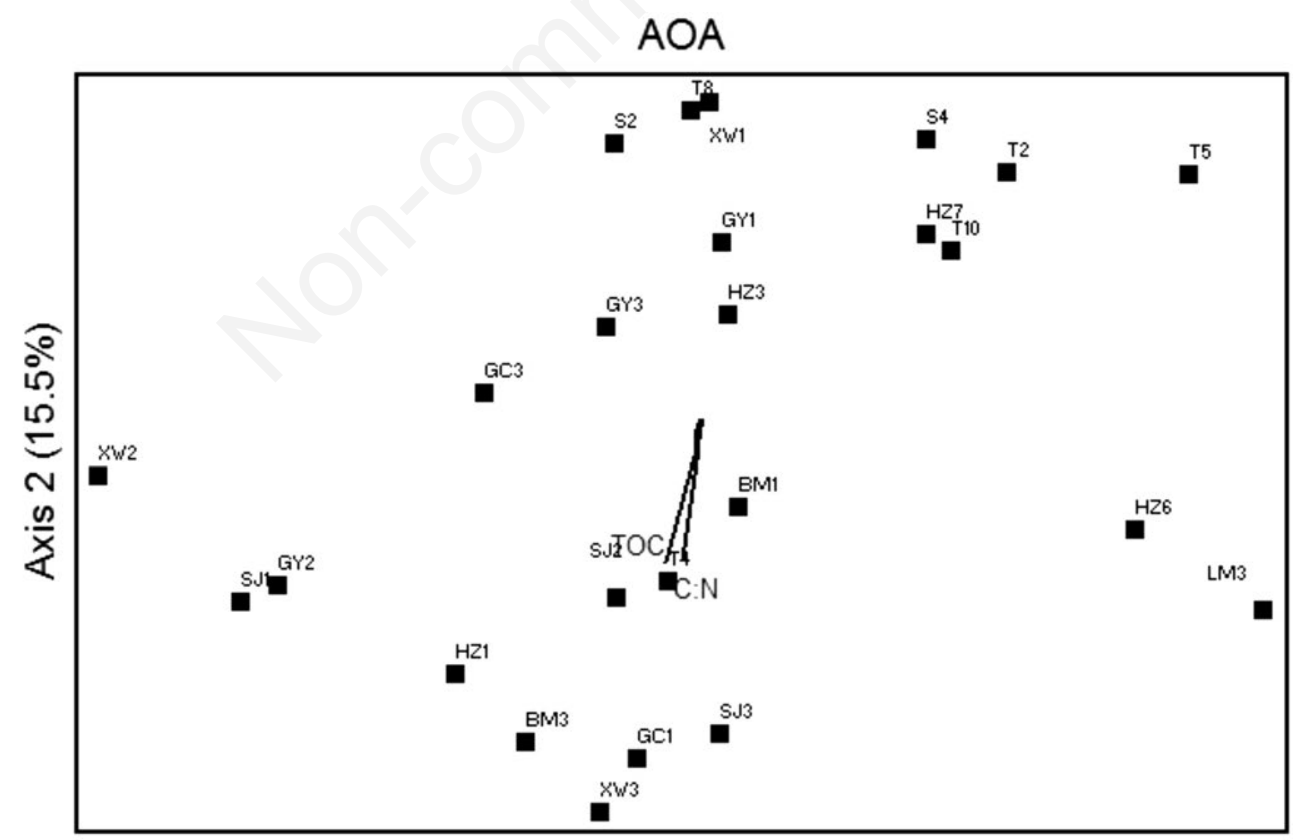

Axis $1(28.3 \%)$

Fig. 6. Non-metric multidimensional scaling analysis of effects of the different environmental factors on the ammonia-oxidizing archaea (AOA) community structure. It was determined by T-RFLP analysis of amoA genes. The environmental factors were incorporated in the analysis using vector fitting with ordination scores. Only those with $\mathrm{R}^{2}>0.2$ are included. Square scatters represent sample sites; arrows represent environmental factors of the sediment pore water. 
2009; Herrmann et al., 2009; Jia and Conrad, 2009; Wu et al., 2010; Yao et al., 2011; Zeng et al., 2012; Hu et al., 2013). Moreover some studies suggested that no significant correlation appeared between $\mathrm{pH}$ and the relative abundance of AOA and AOB (Di et al., 2009; Hou et al., 2013). Contradictory results concerning the effect of $\mathrm{pH}$ on AOA abundance could be explained by differences in the physiological diversity within the archaeal communities present in freshwater sediment.

The community structure of AOA and AOB did not shift with the trophic status of overlying water in Lake Taihu though other researchers stated that the AOA or AOB community structure could vary in high mountain lake or eutrouphic lakes (Herrmann et al., 2009; Wu et al., 2010; Hou et al., 2013). The NMS ordination of the AOA communities does not show a separation between the samples from the ecological type in freshwater sediment. Although weak correlations were found between the AOA community structures and the TOCs, which suggest that the TOCs might play a role in driving the AOA community composition.

Phylogenetic analysis indicated that most AOA amoA gene sequences in this study were closely related to uncultured sediment AOA found at other places. The sequences affiliated with the Crenarchaeotal Group (CG) I.1b (S) were all derived from the eutrophic zones, whereas the CG I.1a (M) sequences were affiliated with both zones. A phylogenetic tree also showed that the most closely related M2 sequences were all from the estuary or Lake Taihu sediments (Mosier and Francis, 2008; Wu et al., 2010; Jin et al., 2011). The affiliation of sequences obtained from freshwater environments with sequences derived from marine and soil habitats, wastewater treatment plants, and hot springs indicates that the phylogeny of archaeal amo $A$ is not primarily linked to general habitat types, as was originally proposed (Yao et al., 2011). The results obtained in this study suggest that ecosysterm structure related to ecological type lakes, such as $\mathrm{pH}$ and TOC in pore water of sediment, may play a critical role in the phylogenetic affiliation of freshwater AOA.

AOB results were also consistent with previous reports that two genera Nitrosomonas and Nitrosospira were the dominant AOB in sediments or benthic compartment (Kowalchuk and Stephen, 2001; Coci et al., 2008; Mosier and Francis, 2008; Chen et al., 2009; Jin et al., 2011; Zhang et al., 2011). Nitrosospira-like sequences were ubiquitous and dominated at all sites, whereas lots of $N$. communis sequences appeared in eutrophic zones. All the retrieved AOB sequences were similar to amoA genes within the genus Nitrosospira, which was the most frequently found beta proteobacterial ammonia oxidizer in soil (Wessen et al., 2011). This spatial heterogeneity could be explained mainly by nitrogen contents in the lake zones studied. Because of their high affinity with resources re- quired for their growth and demand for a selective environment, they could be detected in most oligotrophic freshwater environments and some eutrophic lake sediment. AOB sequences belonging to $N$. communis lineage, although infrequently detected in freshwater environments, exhibit strong heterogeneity according to the ecophysiological traits of their members. They were often obtained from neutral agricultural soils and sewage from wastewater treatment plants too, which indicate that $\mathrm{AOB}$ species can be divided in ecotypes (Koops and Pommerening-Roser, 2001; Cebron et al., 2003; Chen et al., 2009).

\section{CONCLUSIONS}

In conclusion, we have shown that bacterial and archaeal ammonia oxidizers exhibit spatial patterns in freshwater sediment across a large geographical scale. Archaeal amoA far outnumbered bacterial amoA at most sites with the lower concentration of the organic matter. The content of the TOC exhibited significant negative correlations with the abundance of AOA. All archaeal amoA sequences fell within either Crenarchaeotal Group (CG) I.1b or CGI.1a subgroup, and all AOB clustered with genus Nitrosomonas or Nitrosospira. The information acquired in this study elucidates the role of ammonia-oxidizing archaea and ammonia-oxidizing bacteria in the nitrogen cycle of freshwater ecosystems. Future research should include a more extensive spatio-temporal investigation, a breakdown of AOA or AOB transcript abundance and a more precise nitrification measurement.

\section{ACKNOWLEDGMENTS}

This work was supported by grants from the National Special Program of Water Environment (2012ZX07101006) and National Basic Research Program of China (2008CB418102).

\section{REFERENCES}

Altmann D, Stief P, Amann R, De Beer D, 2004. Nitrification in freshwater sediments as influenced by insect larvae: quantification by microsensors and fluorescence in situ hybridization. Microb. Ecol. 48:145-153.

Auguet JC, Casamayor EO, 2013. Partitioning of Thaumarchaeota populations along environmental gradients in high mountain lakes. FEMS Microb. Ecol. 84:154-164.

Bannert A, Kleineidam K, Wissing L, Mueller-Niggemann C, Vogelsang V, Welzl G, Cao Z, Schloter M, 2011. Changes in diversity and functional gene abundances of microbial communities involved in nitrogen fixation, nitrification, and denitrification in a tidal wetland versus paddy soils cultivated for different time periods. Appl. Environ. Microbiol. 77:6109-6116.

Beman JM, Francis CA, 2006. Diversity of ammonia-oxidizing archaea and bacteria in the sediments of a hypernutrified subtropical estuary: Bahia del Tobari, Mexico. Appl. Environ. Microbiol. 72:7767-7777. 
Bouskill NJ, Eveillard D, Chien D, Jayakumar A, Ward BB, 2012. Environmental factors determining ammonia-oxidizing organism distribution and diversity in marine environments. Environ. Microbiol. 14:714-729.

Cao H, Li M, Hong Y, Gu JD, 2011. Diversity and abundance of ammonia-oxidizing archaea and bacteria in polluted mangrove sediment. Syst. Appl. Microbiol. 34:513-523.

Cebron A, Berthe T, Garnier J, 2003. Nitrification and nitrifying bacteria in the lower Seine River and estuary (France). Appl. Environ. Microbiol. 69:7091-7100.

Chen GY, Qiu SL, Zhou YY, 2009. Diversity and abundance of ammonia-oxidizing bacteria in eutrophic and oligotrophic basins of a shallow Chinese lake (Lake Donghu). Res. Microbiol. 160:173-178.

Chen Z, Liu J, Wu M, Xie X, Wu J, Wei W, 2012. Differentiated response of denitrifying communities to fertilization regime in paddy soil. Microb. Ecol. 63:446-459.

Coci M, Bodelier PL, Laanbroek HJ, 2008. Epiphyton as a niche for ammonia-oxidizing bacteria: detailed comparison with benthic and pelagic compartments in shallow freshwater lakes. Appl. Environ. Microbiol. 74:1963-1971.

Covich AP, Palmer MA, Crowl TA, 1999. The Role of Benthic Invertebrate Species in Freshwater Ecosystems: Zoobenthic species influence energy flows and nutrient cycling. BioScience 49:119-127.

Di HJ, Cameron KC, Shen JP, S.Winefield C, Callaghan MO, Bowatte S, He JZ, 2009. Nitrification driven by bacteria and not archaea in nitrogen-rich grassland soils. Nature Geosci. 2:621-624.

Erguder TH, Boon N, Wittebolle L, Marzorati M, Verstraete W, 2009. Environmental factors shaping the ecological niches of ammonia-oxidizing archaea. FEMS Microbiol. Rev. 33:855-869.

Francis CA, Roberts KJ, Beman JM, Santoro AE, Oakley BB, 2005. Ubiquity and diversity of ammonia-oxidizing archaea in water columns and sediments of the ocean. P Natl. Acad. Sci. USA 102:14683-14688.

Hallin S, Jones CM, Schloter M, Philippot L, 2009. Relationship between $\mathrm{N}$-cycling communities and ecosystem functioning in a 50-year-old fertilization experiment. ISME J. 3:597-605.

He JZ, Shen JP, Zhang LM, Zhu YG, Zheng YM, Xu MG, Di $\mathrm{H}, 2007$. Quantitative analyses of the abundance and composition of ammonia-oxidizing bacteria and ammonia-oxidizing archaea of a Chinese upland red soil under long-term fertilization practices. Environ. Microbiol. 9:2364-2374.

Herrmann M, Saunders AM, Schramm A, 2009. Effect of lake trophic status and rooted macrophytes on community composition and abundance of ammonia-oxidizing prokaryotes in freshwater sediments. Appl. Environ. Microbiol. 75: 3127-3136.

Herrmann M, Scheibe A, Avrahami S, Kusel K, 2011. Ammonium availability affects the ratio of ammonia-oxidizing bacteria to ammonia-oxidizing archaea in simulated creek ecosystems. Appl. Environ. Microbiol. 77:1896-1899.

Horz HP, Barbrook A, Field CB, Bohannan BJ, 2004. Ammonia-oxidizing bacteria respond to multifactorial global change. P. Natl. Acad. Sci. USA 101:15136-15141.

Hou J, Song C, Cao X, Zhou Y, 2013. Shifts between ammoniaoxidizing bacteria and archaea in relation to nitrification potential across trophic gradients in two large Chinese lakes
(Lake Taihu and Lake Chaohu). Water Res. 47:2285-2296.

Hu HW, Zhang LM, Dai Y, Di HJ, He JZ, 2013. pH-dependent distribution of soil ammonia oxidizers across a large geographical scale as revealed by high-throughput pyrosequencing. J. Soil. Sediment. 13:1439-1449.

Hugoni M, Etien S, Bourges A, Lepere C, Domaizon I, Mallet C, Bronner G, Debroas D, Mary I, 2013. Dynamics of ammonia-oxidizing Archaea and Bacteria in contrasted freshwater ecosystems. Res. Microbiol. 164:360-370.

Isobe K, Koba K, Suwa Y, Ikutani J, Fang Y, Yoh M, Mo J, Otsuka S, Senoo K, 2012. High abundance of ammonia-oxidizing archaea in acidified subtropical forest soils in southern China after long-term N deposition. FEMS Microbiol. Ecol. 80:193-203.

Jia Z, Conrad R, 2009. Bacteria rather than Archaea dominate microbial ammonia oxidation in an agricultural soil. Environ. Microbiol. 11:1658-1671.

Jin T, Zhang T, Ye L, Lee OO, Wong YH, Qian PY, 2011. Diversity and quantity of ammonia-oxidizing Archaea and Bacteria in sediment of the Pearl River estuary, China. Appl. Microbiol. Biotechnol. 90:1137-1145.

$\mathrm{Ke}$ X, Lu Y, 2012. Adaptation of ammonia-oxidizing microorganisms to environment shift of paddy field soil. FEMS Microbiol. Ecol. 80:87-97.

Konneke M, Bernhard AE, De La Torre JR, Walker CB, Waterbury JB, Stahl DA, 2005. Isolation of an autotrophic ammonia-oxidizing marine archaeon. Nature 437:543-546.

Kontanis EJ, Reed FA, 2006. Evaluation of real-time PCR amplification efficiencies to detect PCR inhibitors. J. Forensic Sci. 51:795-804.

Koops H-P, Pommerening-Roser A, 2001. Distribution and ecophysiology of the nitrifying bacteria emphasizing cultured species. FEMS Microbiol. Ecol. 37:1-9.

Kowalchuk GA, Stephen JR, 2001. Ammonia-oxidizing bacteria: a model for molecular microbial ecology. Annu. Rev. Microbiol. 55:485-529.

Kurola J, Salkinoja-Salonen M, Aarnio T, Hultman J, Romantschuk M, 2005. Activity, diversity and population size of ammonia-oxidising bacteria in oil-contaminated landfarming soil. FEMS Microbiol. Lett. 250:33-38.

Mosier AC, Francis CA, 2008. Relative abundance and diversity of ammonia-oxidizing archaea and bacteria in the San Francisco Bay estuary. Environ. Microbiol. 10:3002-3016.

Qin B, 2009. Lake eutrophication: Control countermeasures and recycling exploitation. Ecol. Eng. 35:1569-1573.

Qinglong W, Yucheng W, Xing P, Huabing L, Jin Z, 2013. [Impacts of regime shift between phytoplankton and macrophyte on the microbial community structure and its carbon cycling in lakes].[Article in Chinese with English Abstract]. Microbiol. China 40:87-97.

Reed DW, Smith JM, Francis CA, Fujita Y, 2010. Responses of ammonia-oxidizing bacterial and archaeal populations to organic nitrogen amendments in low-nutrient groundwater. Appl. Environ. Microbiol. 76:2517-2523.

Rotthauwe JH, Witzel KP, Liesack W, 1997. The ammonia monooxygenase structural gene amoA as a functional marker: molecular fine-scale analysis of natural ammoniaoxidizing populations. Appl. Environ. Microbiol. 63: 4704-4712.

Scheffer M, Hosper SH, Meijer ML, Moss B, Jeppesen E, 1993. 
Alternative equilibria in shallow lakes. Trends Ecol. Evol. $8: 275-279$.

Schloss PD, Westcott SL, Ryabin T, Hall JR, Hartmann M, Hollister EB, Lesniewski RA, Oakley BB, Parks DH, Robinson CJ, Sahl JW, Stres B, Thallinger GG, Van Horn DJ, Weber CF, 2009. Introducing mothur: open-source, platform-independent, community-supported software for describing and comparing microbial communities. Appl. Environ. Microbiol. 75:7537-7541.

Tournaa M, Stieglmeiera M, Anja Spanga MK, Schintlmeisterc A, Tim Uricha, Engeld M, Schloterd M, Wagnerc M, Richterc A, Schlepera C, 2011. Nitrososphaera viennensis, an ammonia oxidizing archaeon from soil. P. Natl. Acad. Sci. USA 108:8420-8425.

Vissers EW, Blaga CI, Bodelier PL, Muyzer G, Schleper C, Sinninghe Damste JS, Tourna M, Laanbroek HJ, 2013. Seasonal and vertical distribution of putative ammonia-oxidizing thaumarchaeotal communities in an oligotrophic lake. FEMS Microbiol. Ecol. 83:515-526.

Wessén E, Nybergb K, Janssonc JK, Hallina S, 2010. Responses of bacterial and archaeal ammonia oxidizers to soil organic and fertilizer amendments under long-term management. Appl. Soil Ecol. 45:193-200.

Wessen E, Soderstrom M, Stenberg M, Bru D, Hellman M,
Welsh A, Thomsen F, Klemedtson L, Philippot L, Hallin S, 2011. Spatial distribution of ammonia-oxidizing bacteria and archaea across a 44-hectare farm related to ecosystem functioning. ISME J. 5:1213-1225.

Williamson CE, Morris DP, Pace ML, Olson OG, 1999. Dissolved organic carbon and nutrients as regulators of lake ecosystems: resurrection of a more integrated paradigm. Limnol. Oceanogr. 44:795-803.

Wu Y, Xiang Y, Wang J, Zhong J, He J, Wu QL, 2010. Heterogeneity of archaeal and bacterial ammonia-oxidizing communities in Lake Taihu, China. Environ. Microbiol. Rep. 2:569-576

Yao H, Gao Y, Nicol GW, Campbell CD, Prosser JI, Zhang L, Han W, Singh BK, 2011. Links between ammonia oxidizer community structure, abundance, and nitrification potential in acidic soils. Appl. Environ. Microbiol. 77:4618-4625.

Zeng J, Zhao DY, Huang R, Wu QL, 2012. Abundance and community composition of ammonia-oxidizing archaea and bacteria in two different zones of Lake Taihu. Can. J. Microbiol. 58:1018-1026.

Zhang T, Ye L, Tong AH, Shao MF, Lok S, 2011. Ammonia-oxidizing archaea and ammonia-oxidizing bacteria in six fullscale wastewater treatment bioreactors. Appl. Environ. Microbiol. 91:1215-1225. 


\title{
Spatial distribution of ammonia-oxidizing archaea and bacteria across eight freshwater lakes in sediments from Jiangsu of China
}

\author{
Xu SUN, Aili WANG, Liuyan YANG, ${ }^{*}$ Liyun GUO, Qiankun CHEN, Zhixin HU, Lijuan JIANG, Lin XIAO
}

State Key Laboratory of Pollution Control and Resource Reuse, School of the Environment, Nanjing University, Nanjing 210046, China

*Corresponding author: yangly@nju.edu.cn

Supplementary Tab. 1. The ratio of submerged plants to phytoplankton in different seasons from different lakes.

\begin{tabular}{|c|c|c|c|c|c|}
\hline & July 2011 & December 2011 & February 2012 & May 2012 & Average \\
\hline LM1 & 0.00 & 0.00 & 11.14 & 35.94 & 11.66 \\
\hline LM2 & 0.00 & 0.00 & 15.14 & 47.94 & 15.62 \\
\hline LM3 & 0.00 & 0.00 & 10.14 & 37.94 & 12.76 \\
\hline BM1 & 31.79 & 39.74 & 51.28 & 58.04 & 45.91 \\
\hline BM3 & 195.10 & 97.84 & 0.00 & 253.02 & 122.63 \\
\hline GC1 & 12.86 & 43.13 & 0.00 & 5.89 & 21.00 \\
\hline GC3 & 4.21 & 1.00 & 0.00 & 2.55 & 2.05 \\
\hline GY1 & 91.49 & 4.24 & 0.00 & 25.29 & 42.47 \\
\hline GY2 & 49.08 & 0.00 & 2.44 & 0.00 & 24.09 \\
\hline GY3 & 3.91 & 216.55 & 90.82 & 716.48 & 185.33 \\
\hline S2 & 17.95 & 12.08 & 0.00 & 0.00 & 8.15 \\
\hline T8 & 0.99 & 18.90 & 0.00 & 48.39 & 34.63 \\
\hline T10 & 818.25 & 3509.45 & 0.00 & 242.18 & 467.42 \\
\hline XW1 & 0.00 & 0.00 & 0.00 & 0.00 & 0.00 \\
\hline XW2 & 0.00 & 0.00 & 0.00 & 0.00 & 0.00 \\
\hline XW3 & 0.00 & 0.00 & 0.00 & 0.00 & 0.00 \\
\hline SJ1 & 0.00 & 0.00 & 0.00 & 0.00 & 0.00 \\
\hline SJ2 & 0.00 & 0.00 & 0.00 & 0.00 & 0.00 \\
\hline SJ3 & 0.00 & 0.00 & 0.00 & 0.00 & 0.00 \\
\hline $\mathrm{T} 4$ & 0.00 & 0.00 & 0.00 & 0.00 & 0.00 \\
\hline T2 & 0.00 & 0.00 & 0.00 & 0.00 & 0.00 \\
\hline T5 & 0.00 & 0.00 & 0.00 & 0.00 & 0.00 \\
\hline S4 & 0.00 & 0.00 & 0.00 & 0.00 & 0.00 \\
\hline $\mathrm{HZ1}$ & 0.52 & 0.00 & 0.00 & 0.00 & 0.12 \\
\hline HZ3 & 0.00 & 0.00 & 0.00 & 0.00 & 0.00 \\
\hline HZ6 & 0.00 & 1.54 & 0.00 & 0.00 & 0.27 \\
\hline $\mathrm{HZ7}$ & 0.03 & 0.00 & 0.00 & 0.00 & 0.01 \\
\hline HZ8 & 0.00 & 0.00 & 0.00 & 0.00 & 0.00 \\
\hline HZ9 & 0.04 & 0.00 & 0.00 & 0.00 & 0.00 \\
\hline
\end{tabular}

Zero values of submerged plant biomass are plotted as $0.01 \mathrm{~g} \mathrm{~m}^{-2}$. According to the ratio of submersed plants to phytoplankton in different seasons from each of the different lakes, all sites could be clearly characterized as A-type zones (with an average ratio below 1) or T-type zones (transitional type with an average ratio between 1 and 100) and M-type zones (with an average ratio above 100) in the different lakes. 